\title{
Vote-by-Mail: COVID-19 and the 2020 Presidential Primaries
}

\author{
Sarah Niebler ${ }^{1}$ \\ (C) Springer Science+Business Media, LLC, part of Springer Nature 2020
}

\begin{abstract}
In this year of pandemic, it seems assured that a record number of citizens will choose to vote by mail. But approval of this method of voting appears increasingly divided along partisan lines, thanks in part to President Trump's declamations. Evidence from the presidential primaries held earlier this year indicates that allegiance to the president, as well as relative lack of concern about the COVID-19 virus, made voters less likely to choose to vote by mail.
\end{abstract}

Keywords Vote by mail $\cdot$ Covid-19 $\cdot 2020$ presidential primaries $\cdot$ Election administration

Election administration is once again part of the national conversation in the United States. The ways that voters cast their ballots are relatively obscure matters to most individuals most of the time. Prominent national events, however, can raise the salience of the issue. After the 2000 presidential election and the vote-counting debacle in Florida, the merits of using punch cards was called into question. With bipartisan consensus in 2002, Congress passed, and President Bush signed, the "Help America Vote Act," which eliminated punch cards and lever machines and increased electronic voting in many states. With evidence of Russian attempts to hack into voting machine systems in the 2016 election, voters again began to consider whether their votes were being counted securely and accurately. Some states began to decertify many of those electronic voting machines purchased after the 2000 election. The goal was to return to a voting system that had a paper trail. Now, with the onset of the COVID-19 global pandemic, the safety of voting in-person is questioned and a national conversation about vote-by-mail (VBM) has begun.

All states have always had options for voters who are absent from the precinct or unable to get to the polls due to infirmness or illness on Election Day to cast their ballots by mail. But in the 2016 presidential elections, just three states Colorado, Oregon, and Washington - conducted all voting by mail. By 2018 all Utah counties had implemented vote-by-

Sarah Niebler

nieblers@dickinson.edu

1 Dickinson College, 28 N College St, Carlisle, PA 17013, USA mail (Franchi 2020), and Hawaii passed a bill in 2019 (Hawaii Office of Elections 2020) allowing that state to implement elections by mail beginning in 2020 . However, now because of COVID-19, twenty states plus the District of Columbia have altered their election rules this year, and at least $83 \%$ of Americans will be permitted to cast their ballots by mail in November (Rabinowitz and Mayes 2020).

While COVID-19 would likely have been enough to bring the VBM conversation to the forefront, President Donald Trump heightens attention by tweeting about it and discussing it publicly. For instance, Trump tweeted May 26, "There is NO WAY (ZERO!) that Mail-In Ballots will be anything less than substantially fraudulent. Mail boxes will be robbed, ballots will be forged $\&$ even illegally printed out \& fraudulently signed" (Trump 2020a, capitalization in original). Despite that tweet earning a fact-check notation from the social media company, two days later Trump reiterated his concerns about VBM: "MAIL-IN VOTING WILL LEAD TO MASSIVE FRAUD AND ABUSE. IT WILL ALSO LEAD TO THE END OF OUR GREAT REPUBLICAN PARTY. WE CAN NEVER LET THIS TRAGEDY BEFALL OUR NATION" (Trump 2020b, capitalization in original). Since May, Trump has continued to make inaccurate statements about the safety and security of VBM, all while encouraging his supporters to make use of it as a mechanism to cast their own ballots (Chalfant 2020). While the full implications of COVID-19 and Trump's politicization of vote-by-mail remain to be seen, we can examine election returns from several states in the 2016 and 2020 presidential primaries to see how voters are responding to the changing circumstances surrounding how they cast their ballots. 
In this paper, I briefly examine existing scholarship on VBM, specifically its impact on turnout and vote choice. Since the lockdowns associated with COVID-19 occurred in the middle of the 2020 presidential primary season, we can consider how VBM changed as a result. I look at several states' 2020 presidential primary returns, considering how the timing of the presidential primaries and the onset of COVID-19 affected how Americans cast their ballots. Finally, I conclude by thinking about what the November elections might look like, and the future of VBM beyond 2020 .

\section{Impact of VBM on Turnout}

Much of the scholarship on the impact of VBM focuses on the issue of turnout. Early scholarship on the reform indicated it may have significant positive impact on turnout, especially in early-adopting states with already high turnout, such as Oregon (Southwell and Burchett 2000, Richey 2008). However, more recent scholarship finds less clear-cut positive effects on turnout. Southwell (2010) finds that turnout increases in presidential elections, but not in primaries and offyear elections, while Gronke and Miller (2012) argue that any turnout effects of VBM are likely limited to sub-federal elections.

In terms of who is likely to use VBM, Southwell (2004) found turnout increased among women, young people, the disabled, and homemakers, while Gerber et al. (2013) see increases among infrequent, nonhabitual voters. Berinsky et al. $(2001,2005)$ find that VBM reforms increase socioeconomic inequalities in the voter pool. Younger voters and others who are more transitory may actually find it harder to vote by mail than in-person at the polls (Southwell 2010).

Taken together, VBM appears to show small increases in voter turnout, but not widespread increases that might be expected based on its perceived convenience. This is in line with other scholarship examining voting reforms like no-excuse absentee voting and early voting (Fitzgerald 2005, Gronke et al. 2007, Larocca and Klemanski 2011, Burden et al. 2014). It is important to note, however, that VBM's positive effects of voter turnout are likely contingent upon get-out-thevote efforts that orient voters toward a new method of casting ballots (Arceneaux et al. 2012, Hassell 2017).

Menger and Stein (2020) surveyed voters in Colorado and found that despite being mailed a ballot, a number of voters still chose to return their ballot in person. They conclude that the "strongest determinant of how [voters] return their ballot, by mail or in person, is trust in the USPS [United States Postal Service]" (Menger and Stein 2020, 204). In the study, which took place in 2014 , less than $20 \%$ of respondents reported distrusting the USPS. ${ }^{1}$

\section{Partisan Effects of VBM}

While President Trump has claimed that VBM would disproportionately benefit Democrats, political science scholarship has not found this to be the case. Examining VBM in Oregon, Southwell (2004) claims that "neither of the two major parties have much to lose or gain from vote by mail" (92). Burden et al. (2017) find that the type of reform affects which political party stands to gain, with Election-Day voter registration being more likely to benefit Democrats while early voting, which can be done in person or by mail, benefits Republicans (573). An early study examining the expansion of VBM due to the COVID-19 pandemic claims that while "implementing universal VBM has no apparent effect on either the share of turned-out voters who are Democrats or the share of voters that go to Democratic candidates" (Thompson et al. 2020, 2), we should be aware that existing studies have examined only what happens when VBM was rolled out in normal circumstances, not what might happen if VBM is implemented as a result of COVID-19. The impact of VBM on voter turnout under those conditions is likely driven by whether COVID-19 itself disproportionally deters Democrats or Republicans from voting.

\section{Other Effects of VBM}

In addition to the effects of VBM on turnout, both overall and in a partisan context, other impacts of the voting reform are worth noting. Since VBM allows voters to complete their ballot on their own time, studies have found decreases in the amount of under- or roll-off voting ${ }^{2}$ (Southwell 2009, Menger et al. 2018, but see Alvarez et al. 2011, which finds an increase in the residual vote rate $^{3}$ ). VBM elections are also less

\footnotetext{
${ }^{1}$ High levels of trust in the USPS were also found in a Gallup survey taken around the same time (Ander and Swift 2014). In this study, over two-thirds of all respondents said the U.S. Postal Service was doing an "excellent" or "good" job, with support being highest among the youngest respondents. A USPS report produced by the Office of the Inspector General (2018) finds that "while millennials check their mail less frequently, their overall satisfaction with the Postal Services is similar to older age cohorts" (3). Neither Ander and Swift (2014) nor the OIG (2018) report provide any differences between Democrats and Republicans with respect to satisfaction and/or trust in the USPS, likely indicating they were not significant.

${ }^{2}$ An undervote occurs when a voter casts a ballot, but votes for a fewer number of candidates in a given race than is legally permitted. Roll-off voting occurs when a voter casts legally valid votes in only races at the top of the ballot, but leaves the remainder of the ballot blank.

${ }^{3}$ The residual vote rate is the proportion of ballots that contain either undervotes or overvotes. Overvoting is when a voter votes for a greater number of candidates in a given race than is legally permitted.
} 
expensive to administer than are in-person elections (Southwell 2014).

Clark (2020) finds that VBM leads to lower levels of confidence in election processes overall, but only after initial implementation; after one election cycle, confidence levels return to their previous levels. In terms of public support for VBM, Stewart (2011) finds low levels of support for the reform in the early 2000s, even in states that had already implemented it. More recently, Clinton et al. (2020) find that public support for VBM increased in April as lockdowns became more commonplace throughout the U.S., but then decreased in May as the issue became polarized. They argue, however, that the decline in support was mostly because Republicans became less concerned with catching COVID-19; support for VBM remained stable among Republicans who were concerned with the spread of the virus.

\section{Methodology}

My research examines adjustments that states made to their voting processes in light of the COVID-19 pandemic, and how VBM changed in light of state-wide lockdowns and postponements of presidential primaries. Reports of the COVID19 outbreak in China first appeared in The New York Times ${ }^{4}$ and The Washington Post ${ }^{5}$ in early January, and the virus was likely present in the U.S. as early as January 19 (Holshue et al. 2020). But widespread lockdowns in the U.S. did not begin until late March, ${ }^{6}$ causing a number of states to delay their presidential primary elections (NCSL 2020).

In this article, I examine the results from several states where absentee ballots are reported separately and compare 2020 presidential primary election results across several dimensions. The first point of comparison is with respect to VBM rates in states between 2016 and 2020. I can examine this in states that held their presidential primary contests before widespread lockdowns occurred and in those that held their primary contests after the lockdowns (including those that rescheduled their primaries to occur later in the calendar year). The second, and likely more interesting, dimension is related to partisanship. In these analyses, I compare absentee and VBM rates between Democrats and Republicans in states

\footnotetext{
${ }^{4}$ Wee, Sui-Lee and Donald G. McNeil Jr. 2020. "China Identifies New Virus Causing Pneumonia-like Illness.” New York Times. January 8, 2020. Accessed on September 6, 2020. Available from: https://www.nytimes.com/2020/01/08/ health/china-pneumonia-outbreak-virus.html.

${ }^{5}$ Shih, Gerry and Lena H. Sun. 2020. "China identifies new strain of coronavirus as source of pneumonia outbreak.” Washington Post. January 9, 2020. Accessed on September 6, 2020. Available from: https://www. washingtonpost.com/world/asia_pacific/china-identifies-new-strain-ofcoronavirus-as-source-of-pneumonia-outbreak/2020/01/09/f2625650-329f11 ea-971b-43bec3ff9860_story.html.

${ }^{6}$ California issued the first statewide lockdown on March 20 at 12 a.m. (KSLA 12 News 2020).
}

that held primaries before and after COVID-19 lockdowns. Finally, I examine whether support for presidential primary candidates, including President Trump, was the same among voters who cast their ballots by mail and among those who cast their ballots in person on Election Day.

Article I, Section 4 of the U.S. Constitution gives the power of election administration to the states. This power includes choosing dates of presidential (and other) primary elections, election equipment, voter registration deadlines, and the method by which individuals are allowed to cast their ballots. Most importantly for my purposes, states decide how to tally and report absentee and VBM ballot results. According to the National Council of State Legislatures, most election results are reported by precincts, but the reporting of absentee ballots and whether they are reported within or separate from precinct totals differs by state (VOPP NCSL 2020). In my analysis, I include states that reported presidential primary vote totals with absentee/VBM totals reported separately, which leads me to be able to include six states in my analysis. Three of the included states - New Hampshire, South Carolina, and North Carolina - held their presidential primaries before the lockdowns. ${ }^{7}$ The remaining three - Maryland, Rhode Island, and Delaware - rescheduled their primary elections due to the pandemic. ${ }^{8}$

\section{Results}

Figure 1 illustrates the percentage of voters who cast their ballots by mail in each of our six states in both 2016 and 2020. Across the board, VBM rates were low in 2016, ranging from $1.7 \%$ in North Carolina to $6.6 \%$ in New Hampshire. VBM rates in 2020, however, were highly contingent on whether a state held its presidential primary prior to the outbreak of COVID-19 in the U.S. or afterward. VBM rates in the states with presidential primaries prior to mid-March 2020 were similar to the VBM rates in those states in 2016. In states with presidential primaries that were postponed, however, VBM rates were 15 to 20 times higher in 2020 than they were in 2016.

Figure 2 shows the VBM rate separately for Democratic and Republican voters in just the 2020 presidential primary. South Carolina canceled its presidential primary for Republican voters (Rojas 2020). In North Carolina, however, the only other state with an early presidential primary for which VBM rates are reported separately by political party,

\footnotetext{
${ }^{7}$ New Hampshire's presidential primary was the first in the nation and it was held on February 11. South Carolina's primary was on February 29, but only for Democratic voters as the Republican Party canceled its primary. North Carolina's presidential primary was on March 3 .

${ }^{8}$ All three states' presidential primaries were originally scheduled for April 28. Maryland and Rhode Island postponed their primaries until June 2 while Delaware ultimately held its primary on July 7 .
} 
Fig. 1 Comparison of VBM Rates in Presidential Primaries in 2016 and 2020.* South Carolina's VBM rate is reported only for Democratic voters because the state canceled its Republican primary. All other states' VBM rates are for Democratic and Republican voters.

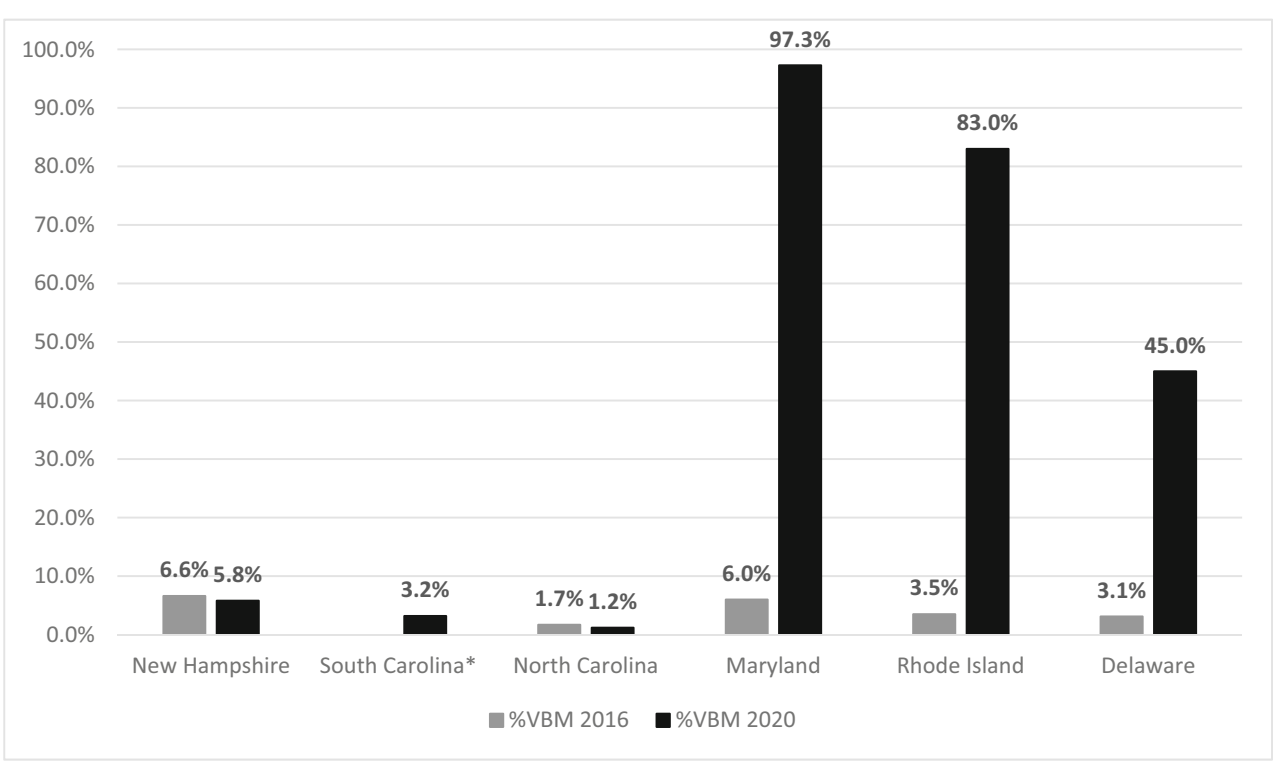

we see no meaningful difference between the percentage of Democratic voters and Republican voters who cast their ballots by mail. In states that postponed their presidential primaries, however, we do see significant differences, especially in Rhode Island and Delaware. In Rhode Island, $85.9 \%$ of Democratic presidential primary votes were cast by mail, compared to $69.3 \%$ of those cast by mail in the Republican presidential primary. In Delaware, the overall rates of VBM were lower, but the difference between the two parties was even greater, with $50.5 \%$ of Democratic votes cast by mail compared to just $29.7 \%$ of Republican votes.

Finally, in Fig. 3 we can examine the heterogeneity of VBM rates within the Republican Party. There were just two candidates on the ballot in Maryland, Trump and former Massachusetts Governor Bill Weld. Maryland's overall VBM rates were high overall, so there is little room for differences between the two candidates. Over $95 \%$ of Trump's and
Weld's votes were cast by mail in the Maryland presidential primary. In the other two states, however, we see that the lower Republican VBM rates we saw in Fig. 2 are driven mostly by the VBM rate among Trump voters, not by the VBM rate among voters casting their ballots for other Republican primary candidates. In Rhode Island, Trump's VBM rate was $67.2 \%$, more than 9 percentage points lower than any other Republican candidate's VBM rate. In Delaware, the VBM rate difference between Trump voters and voters for the other Republican candidate on the ballot was even greater: $65 \%$ of GOP ballots for Rocky De La Fuente in Delaware were cast by mail, as compared to just $24.9 \%$ of those cast for Trump.

Taken together, these results indicate that COVID-19 has had a substantial impact on VBM rates. States that postponed their 2020 presidential primaries have significantly higher VBM rates than do states whose primaries were held prior to
Fig. 2 VBM Rates Among Democratic and Republican Voters in 2020

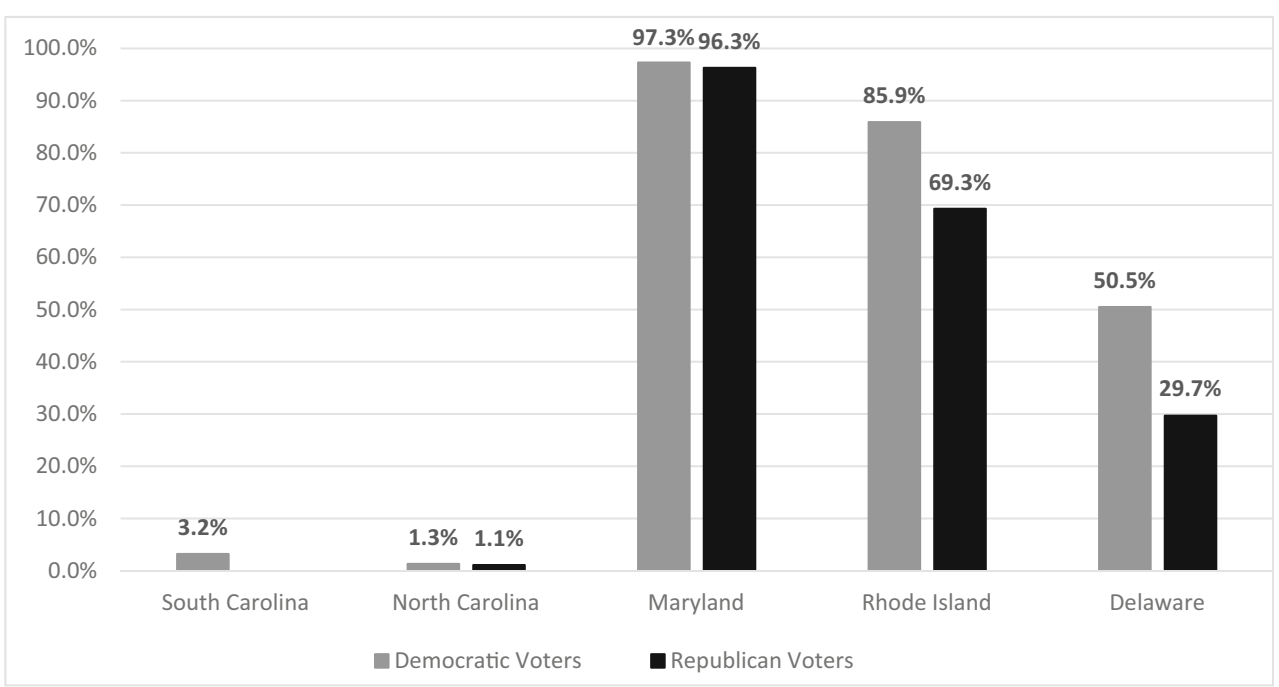


Fig. 3 VBM Rates for Republican Candidates in States with Postponed Presidential Primaries

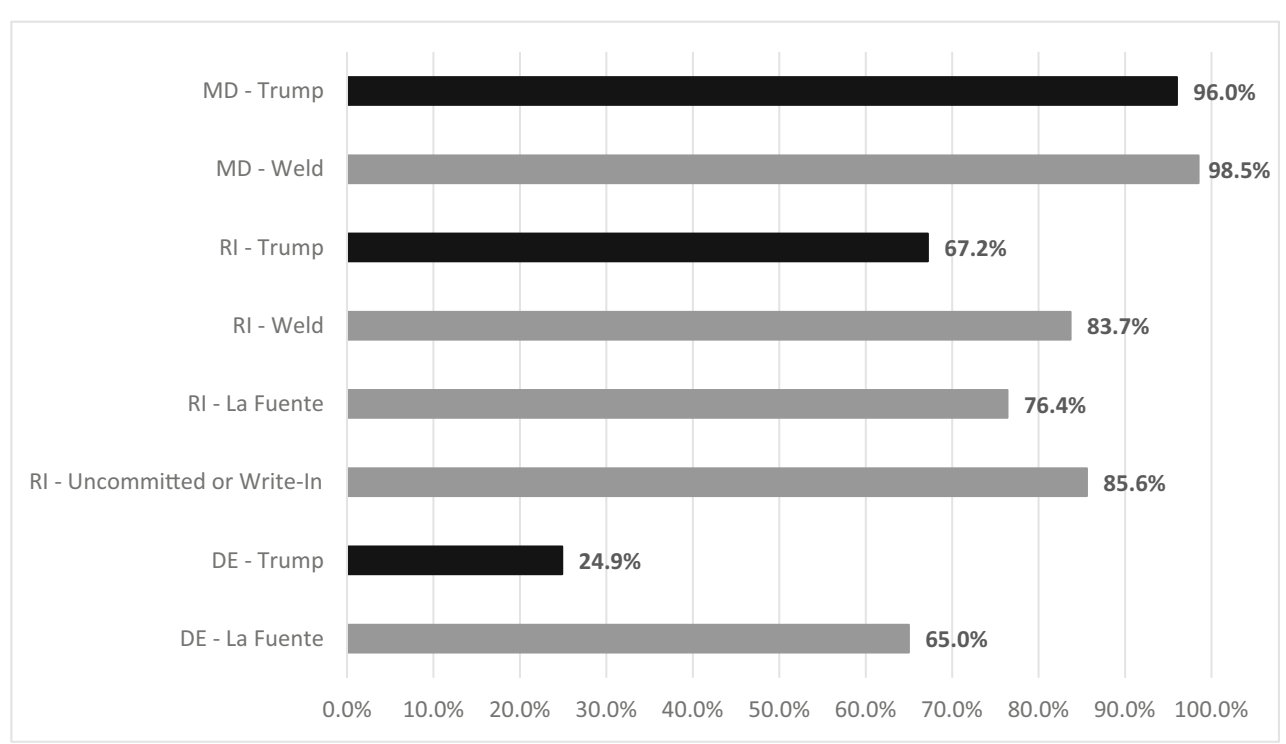

the pandemic's onset in the United States. We also see that voters in Democratic primaries used VBM at higher rates than voters in Republican primaries. Trump voters caused these partisan differences: GOP voters casting their ballots for Trump were much more likely to cast them in person, while voters for Democratic candidates and Republican candidates other than Trump were more likely to cast them by mail.

\section{Discussion and Conclusion}

In the polarized political environment of 2020, we often think purely of differences between Democrats and Republicans. Zaller (1992) shows us that when political elites of differing political parties coalesce around differing positions on an issue, members of the mass public will follow. We see evidence of this in public opinion data on the issue of VBM. A May 2020 Gallup Report finds that while $64 \%$ of all Americans support their state allowing all voters to vote by mail or absentee ballot in November, more than twice the percentage of Democrats favor it as compared to Republicans (83\% to 40\%) (Younis 2020). An August Pew Research Center survey asks the question slightly differently but reports similar gaps between supporters of the dominant political parties' candidates. Fifty-eight percent of Biden supporters said they would prefer to vote by mail in November, while just $19 \%$ of Trump supporters said the same (Gomez and Jones 2020).

With respect to VBM rates in the 2020 presidential primaries, we can observe evidence of heterogeneity within the Republican Party on these issues. Among Republican voters in Delaware, voters who did not support President Trump were more than twice as likely to vote by mail than supporters of the president. Clinton et al. (2020) also find evidence of differences within the Republican Party, arguing that the shift in support for VBM is driven not just by partisanship, but rather concern with catching COVID-19. In other words, Republicans who remain concerned about catching the virus are just as supportive of VBM now as they were prior to Trump's increased comments on the issue, while support for VBM has diminished among Republicans who are not as concerned. Studies undertaken by "The COVID-19 Consortium" (Baum et al., 2020, Lazer et al., 2020) confirm heterogeneity among Republican respondents, but also find it among Democratic respondents; $50 \%$ of Republicans who are concerned about COVID-19 support or strongly support VBM, compared to $32 \%$ of Republicans who are not concerned about the virus. Among Democrats, $82 \%$ who are concerned about COVID-19 support or strongly support VBM, whereas $72 \%$ of those who are not concerned about COVID-19 feel the same.

Where does this leave us for November? I suspect VBM will be likely to appear more partisan and more polarized between Democrats and Republicans, the more Trump talks about the issue. Republicans who are not as supportive of the President, however, are likely less extreme in their opposition to VBM, and Republicans who are concerned about themselves or their loved ones catching COVID-19 more strongly support VBM.

Finally, there have been questions about the speed with which election officials will be able to count and report election results this November. Just as states have a variety of methods by which they tabulate absentee and VBM ballots, they also have differing rules about when they can begin counting ballots that are received by mail. I do think this has the potential to lead to the slower report of results on election night. Furthermore, given that some states tabulate absentee and VBM results at the precinct level and others at the county 
level, it may be difficult for reporters to have a detailed and nuanced understanding of exactly where the outstanding ballots remain to be counted, further slowing their ability to make declarations of winners on November 3.

\section{References}

Alvarez, R. Michael, Dustin Beckett, and Charles Stewart, III. 2011. "Voting Technology, Vote-by-Mail, and Residual Votes in California 1990-2010.” Political Research Quarterly 66(3): 658670.

Ander, Steve and Art Swift. 2014. "Americans Rate Postal Service Highest of 13 Major Agencies" Gallup. Accessed on September 4, 2020. Available from: https://news.gallup.com/poll/179519/ americans-rate-postal-service-highest-major-agencies.aspx.

Arceneaux, Kevin, Thad Kousser, and Megan Mullin. 2012. "Get Out the Vote-by-Mail? A Randomized Field Experiment Testing the Effect of Mobilization in Traditional and Vote-by-Mail Precincts." Political Research Quarterly 65(4): 882-894.

Baum, Matthew A., Katherine Ognyanova, David Lazer, John Della Volpe, Roy H. Perlis, James Druckman, Mauricio Santillana, Alexi Quintana, and Hanyu Chwe. 2020. "The State of the Nation: A 50-State COVID-19 Survey Report \#3: Support for Vote By Mail" www.covidstates.org. Accessed on August 31, 2020. Available from: https://www.kateto.net/covid19/COVID19\% 20CONSORTIUM\%20VOTE\%20BY\%20MAIL\%20FINAL\% 20MAY\%202020.pdf

Berinsky, Adam J., 2005. "The Perverse Consequences of Electoral Reform in the United States." American Politics Research 33(4): 471-491.

Berinsky, Adam J., Nancy Burns, and Michael W. Traugott. 2001. "Who Votes by Mail? A Dynamic Model of the Individual-Level Consequences of Voting-by-Mail Systems." Public Opinion Quarterly 65: 178-197.

Burden, Barry C., David T. Canon, Kenneth R. Mayer, and Donald P. Moynihan. 2014. "Election Laws, Mobilization, and Turnout: The Unanticipated Consequences of Election Reform" American Journal of Political Science 58(1): 95-109.

Burden, Barry C., David T. Canon, Kenneth Mayer, and Donald P. Moynihan. 2017. "The Complicated Partisan Effects of State Election Laws." Political Research Quarterly 70(3): 564-576.

Chalfant, Morgan. 2020. "Trump shifts, encourages vote by mail - in Florida." The Hill. August 4, 2020. Accessed September 7, 2020. Available from: https://thehill.com/homenews/administration/ 510484-trump-in-reversal-encourages-vote-by-mail-in-florida.

Clark, Jesse, Lost in the Mail? Vote by Mail and Voter Confidence (January 17, 2020). MIT Political Science Department Research Paper No. 2020-1, Available at SSRN: https://ssrn.com/abstract= 3523220 or https://doi.org/10.2139/ssrn.3523220

Clinton, Joshua David and Lapinski, John S. and Lentz, Sarah and Pettigrew, Stephen, Trumped by Trump? Public Support for Vote By Mail Voting in Response to the COVID-19 Pandemic (June 16, 2020). Available at SSRN: https://ssrn.com/abstract=3630334 or https://doi.org/10.2139/ssrn.3630334

Fitzgerald, Mary. 2005. "Greater Convenience But Not Greater Turnout: The Impact of Alternative Voting Methods on Electoral Participation in the United States." American Politics Research 33(6): $842-867$

Franchi, John. 2020. "Why Vote By Mail Works in Utah." Fox 13. Accessed on September 6, 2020. Available from: https://www. fox13now.com/news/local-news/why-vote-by-mail-works-in-utah.
Gerber, Alan S., Gregory A. Huber, and Seth J. Hill. 2013. "Identifying the Effect of All-Mail Elections on Turnout: Staggered Reform in the Evergreen State." Political Science Research and Methods 1(1): 91-116.

Gomez, Vianney and Bradley Jones. 2020. "Biden supporters in states where it is hardest to vote by mail are most concerned about voting this fall." PEW Research Center. Accessed on September 6, 2020. Available from: https://www.pewresearch.org/fact-tank/2020/08/ 26/biden-supporters-in-states-where-it-is-hardest-to-vote-by-mailare-most-concerned-about-voting-this-fall/.

Gronke, Paul, Eva Galanes-Rosenbaum, and Peter A. Miller. 2007. "Early Voting and Turnout." PS: Political Science and Politics 40(4): 639-645.

Gronke, Paul, and Peter Miller. 2012. "Voting by Mail and Turnout in Oregon: Revisiting Southwell and Burchett." American Politics Research 40(6): 976-997.

Hassell, Hans J.G. 2017. "Teaching voters new tricks: The effect of partisan absentee vote-by-mail get-out-the-vote efforts." Research and Politics January-March: 1-6.

Hawaii, Office of Elections. 2020. "Hawaii Votes By Mail." State of Hawaii. Accessed September 6, 2020. Available from: https:// elections.hawaii.gov/hawaii-votes-by-mail/.

Holshue, Michelle L., Chas DeBolt, Scott Lindquist, et al. 2020. "First Case of the 2019 Novel Coronavirus in the United States." The New England Journal of Medicine 382: 929-936.

KSLA 12 News. 2020. "California becomes first state to order lockdown." March 20, 2020. Accessed on September 6, 2020. Available from: https://www.ksla.com/2020/03/20/californiabecomes-first-state-order-lockdown/.

Lazer, David, Katherine Ognyanova, Matthew A. Baum, Alexi Quintana, John Della Volpe, James Druckman, Roy H. Perlis, Mauricio Santillana, Hanyu Chwe, and Matthew Simonson. 2020. "The State of the Nation: A 50-State COVID-10 Survey, Report \#7" Update on Vote by Mail" www.covidstates.org. Accessed on August 31, 2010. Available from: https://www.kateto.net/covid19/ COVID19\%20CONSORTIUM\%20REPORT\%207\%20VBM\% 20JULY\%202020.pdf

Larocca, Roger., and John S. Klemanski. 2011. "U.S. State Election Reform and Turnout in Presidential Elections." State Politics \& Policy Quarterly 11(1): 76-101.

Menger, Andrew and Robert M. Stein. 2020. "Choosing the Less Convenient Way to Vote: An Anomaly in Vote by Mail Elections." Political Research Quarterly 71(1): 196-207.

Menger, Andrew, Robert M. Stein, and Greg Vonnahme. 2018. "Reducing the Undervote With Vote by Mail." American Politics Research 46(6): 1039-1064.

Office of the Inspector General. 2018. "Millennials and the Mail." Accessed on September 4, 2020. Available from: https://www. uspsoig.gov/sites/default/files/document-library-files/2018/RARCWP-18-011.pdf.

National Conference of State Legislatures. 2020. "2020 State Primary Election Dates." National Conference of State Legislatures. Accessed on September 6, 2020. Available from: https://www. ncsl.org/research/elections-and-campaigns/2020-state-primaryelection-dates.aspx.

Rabinowitz, Kate and Brittany Renee Mayes. 2020. "At least $83 \%$ of American voters can cast ballots by mail in the fall." The Washington Post. August 20. Accessed September 6, 2020. Available from: https://www.washingtonpost.com/graphics/2020/ politics/vote-by-mail-states/.

Richey, Sean. 2008. "Voting by Mail: Turnout and Institutional Reform in Oregon.” Social Science Quarterly 89(4): 902-915.

Rojas, Rick. 2020. “There's No G.O.P. Primary in South Carolina. Some Republicans Will Vote Anyway." New York Times February 25, 2020. Accessed on September 5, 2020. Available from: https:// 
www.nytimes.com/2020/02/25/us/south-carolina-primaryoperation-chaos.html.

Shih, Gerry and Lena H. Sun. 2020. "China identifies new strain of coronavirus as source of pneumonia outbreak." Washington Post. January 9, 2020. Accessed on September 6, 2020. Available from: https://www.washingtonpost.com/world/asia_pacific/chinaidentifies-new-strain-of-coronavirus-as-source-of-pneumoniaoutbreak/2020/01/09/f2625650-329f-11 ea-971b-43bec3ff9860 story.html.

Southwell, Priscilla L. 2004. "Five Years Later: A Re-Assessment of Oregon's Vote by Mail Electoral Process." PS: Political Science and Politics 37 (1): 89-93.

Southwell, Priscilla L. 2009. “A Panacea for Voter Fatigue? Vote by Mail in the State of Oregon." Journal of Political and Military Sociology 37(2): 195-205.

Southwell, Priscilla L. 2010. "Voting Behavior in Vote-by-Mail Elections." Analyses of Social Issues and Public Policy 10(1): 106-115.

Southwell, Priscilla L., and Justin I. Burchett. 2000. "The Effect of AllMail Elections on Voter Turnout." American Politics Quarterly 28(1): 72-79.

Stewart, Charles. 2011. "Adding Up the Costs and Benefits of Voting by Mail.” Election Law Journal 10(3): 297-301.

Thompson, Daniel M., Jennifer A. Wu, Jesse Yoder, and Andrew B. Hall. 2020. "Universal vote-by-mail has no impact on partisan turnout or vote share." Proceedings of the National Academy of Sciences (PNAS) May 6, 2020. Accessed August 31, 2020. Available from: https://www.pnas.org/content/pnas/early/2020/06/08/2007249117. full.pdf

Trump, Donald J. 2020a. Twitter. May 26, 2020. Accessed September 7 , 2020. Available from: https://twitter.com/realDonaldTrump/status/ 1265255835124539392.
Trump, Donald D. 2020b. Twitter. May 28, 2020. Accessed September 7, 2020. Available from: https://twitter.com/realdonaldtrump/status/ 1266172570983940101.

VOPP (Voting Outside the Polling Place: Absentee, All-Mail and other Voting at Home Options). 2020. "Table 17: How Election Results Are Reported." National Conference of State Legislatures. Accessed on August 31, 2020. Available from: https://www.ncsl. org/research/elections-and-campaigns/vopp-table-17-how-electionresults-are-reported.aspx

Wee, Sui-Lee and Donald G. McNeil Jr. 2020. "China Identifies New Virus Causing Pneumonia-like Illness.” New York Times. January 8, 2020. Accessed on September 6, 2020. Available from: https:// www.nytimes.com/2020/01/08/health/china-pneumonia-outbreakvirus.html.

Younis, Mohamed. 2020. "Most Americans Favor Voting by Mail as Option for November." Gallup. Accessed on September 6, 2020. Available from: https://news.gallup.com/poll/310586/americansfavor-voting-mail-option-november.aspx.

Zaller, John. 1992. The Nature and Origins of Mass Opinion. New York: Cambridge University Press.

Publisher's Note Springer Nature remains neutral with regard to jurisdictional claims in published maps and institutional affiliations.

Sarah Niebler is a professor of political science at Dickinson College. Her research and teaching interests are in American politics, specifically political behavior, campaigns and elections, and public opinion. Her scholarly work is published in the American Journal of Political Science, Legislative Studies Quarterly, Political Communication, the Journal of Public Economics, and American Politics Research, among others. Additionally, her research and analysis have been featured on NPR's "Hidden Brain", and in The Hill and Roll Call. 